Article

\title{
Effects of Shiitake (Lentinus edodes P.) Mushroom Powder and Sodium Tripolyphosphate on Texture and Flavor of Pork Patties
}

\author{
Soonsil Chun ${ }^{1}$, Edgar Chambers IV ${ }^{2, *}$ [C and Delores H. Chambers ${ }^{2}$ \\ 1 Department of Food and Nutrition, Sunchon National University, Jeonnam 57922, Korea; css@sunchon.ac.kr \\ 2 Sensory Analysis and Consumer Behavior, Kansas State University, Manhattan, KS 66506, USA; \\ delores@ksu.edu \\ * Correspondence: eciv@ksu.edu
}

Received: 15 April 2020; Accepted: 6 May 2020; Published: 10 May 2020

\begin{abstract}
Increasing consumer desire for functional food ingredients, including such PRODUCTS as shiitake mushroom (Lentinus edodes P.) powder (SM), demands that the sensory impact of such ingredients be tested in an appropriate food system. Pork patties are a common food in many Asian countries. Pork patties in this study were prepared with and without SM, an ingredient that is gaining popularity around the world. A lexicon for describing the texture and flavor of cooked pork patties, with and without $0.5 \%$ sodium tripolyphosphate (STP), a typical additive to meat, and with varying amounts of SM $(0 \%$ to $6 \%)$ was developed by a highly trained panel to compare sensory properties for each type of patty. The attributes evaluated were juiciness, toughness, rubberiness, mealiness, pork identity (pork ID), meatiness, mushroom, onion, garlic, black pepper, heat/burn, soapy, chemical, animal hair, fatty, salty, sour, bitter, slick, and astringent. An addition of $0.5 \%$ STP produced more intense ratings for soapy, salty, sour, and astringent attributes. Without STP, patties containing shiitake mushroom powder had a more mealy consistency but more pork ID than they did with STP.
\end{abstract}

Keywords: pork; descriptive; sensory; shiitake mushroom; flavor; texture; phosphate

\section{Introduction}

Flavor is one of the most important factors contributing to consumers' perception of the quality of meat products [1,2]. The flavor of pork has not received as much attention as beef and chicken in recent years, although it is one of the most frequently consumed meats worldwide. Raw pork has little odor and only a mild, serum-like taste, which is described as salty, metallic, and bloody-tasting, with a sweet aroma [3,4]. During the cooking process, numerous nonvolatile compounds in meat, including pork, undergo degradation, producing hundreds of volatile compounds that together make up the characteristic "pork" flavor [5]. Similarly, mushrooms can impart flavor properties into the products they are added to. For example, the shiitake mushroom (SM) has a unique flavor compound (lenthionine) [6] and also contains low to moderate levels of umami flavor potentiators, such as 5 'ribonucleotides [7]. The number of nucleotides and other compounds tested and the impact on the savory character commonly associated with the umami taste when mushroom is blended into meat depends on how the mushrooms are processed. Higher levels of heating during mushroom processing has been found to give a more savory flavor to beef patties [8].

Texture is another attribute that consumers notice when judging the quality of meat. European studies of consumers' perceptions of "quality" and "wholesomeness" of the pork they purchase, compared with the same attributes judged after consumption of the pork, showed that consumers tended to 
prefer paler, softer meat when making purchases, even though such attributes had little relationship to their enjoyment of the pork once it was consumed $[1,5,9,10]$.

Shiitake mushrooms (SM) are nutrient-dense. In Asia, these mushrooms are thought to have special medicinal properties with respect to several diseases, including diabetes, anemia, various forms of cancer, and oral health [11-16]. The way in which the mushrooms are prepared can play a role in the nutrient retention. Lee and others [17] found that microwaving and roasting the mushrooms caused the most vitamin and mineral retention. Other authors [18] found that the stipes and caps of shiitake mushroom have different nutritional value, but the same flavor. Several authors have studied the consumer acceptability of meat products with added mushroom powder and found that the products were acceptable $[19,20]$. The use of adjuncts in meat products is becoming more popular as consumers are looking for healthier alternatives to the traditional patty. For example, Taylor et al. [21] investigated the addition of tempeh (a fermented soybean product) into beef patties at varying amounts and found that it affected sensory attributes. Phosphates are known to increase water-binding and stabilize meat emulsions, improve juiciness and tenderness, provide mineral supplementation, and maintain the flavor of processed meat products [22-24]. Phosphate in pork and beef roasts allowed them to be reheated after 1 and 3 days of refrigeration with minimal loss of juiciness, tenderness, or flavor intensity [25]. Phosphates have been shown to increase acceptance of turkey patties [26], but the impact of phosphates on flavor is somewhat dependent on differing human sensitivity to phosphate compounds [27].

Various authors [28-31] have pointed out the importance of studying sensory properties of products, including meat products when adding new ingredients, such as functional ingredients, to existing products. The flavor properties of many foods have been well-described, defined, and referenced. For example, Maughan and Martini [32] found that fresh cooked pork is characterized by such terms as brothy, fatty, salty, sweet, and umami. Other authors [33] showed that consumer acceptance of cooked, stored pork patties increased after the addition of plant extracts containing antioxidants. Storage, particularly at refrigerated temperatures, can result in a warmed-over flavor (WOF) when products are reheated. This occurs largely because of compounds produced from lipid oxidation [34]. Controlling WOF, especially with natural antioxidants, is important because of the increase in precooked meat products $[35,36]$. Various authors have found that mushroom extracts contain antioxidants $[37,38]$, which could potentially reduce WOF in stored pork patties. The mushroom flavor could also mask some off flavors such as WOF, although the mushroom flavor is greatly reduced during drying [39].

The objectives of this study were to a) determine flavor attributes of pork patties when mushroom were added, b) compare the flavors of fresh, cooked pork patties with and without $0.5 \%$ Sodium tripolyphosphate (STP) and with either $0 \%, 2 \%, 4 \%$, or $6 \%$ shiitake mushroom powder (SM), and c) determine the impact of refrigerated storage on cooked pork patties with and without those same levels of compounds.

\section{Materials and Methods}

\subsection{Raw Sample Preparation}

Ground pork was purchased frozen from a local food market in Manhattan, KS (Dillon's, distributed by Kroger Co, Cincinnati, $\mathrm{OH} 45202$ ), thawed in the refrigerator, and processed as patties within $12 \mathrm{~h}$ of purchase. The meat $(800 \mathrm{~g}$ ) for each batch of patties was mixed with iodized salt (Kroger), black pepper (McCormick), garlic powder (McCormick), and water $(48 \mathrm{~mL})$. The recipe was determined based on pre-testing various recipes found online and in cookbooks; the final ingredients and amounts were chosen from among those commonly used in recipes without adding other competing ingredients found in some recipes (e.g., coriander, carrot). The appropriate amount of STP $(0 \%$ or $0.5 \%)$ and shiitake mushroom powder (Jangheung, Korea; $0 \%$ to $6 \%$ ) were added (Table 1 ) and mixed thoroughly using a KitchenAid mixer (model Pro600, Benton Harbor, MI) with a paddle attachment on a medium 
setting for $30 \mathrm{~s}$. Ten patties were prepared with $80 \mathrm{~g}$ of meat mixture using a $9 \mathrm{~cm}$ Tupperware ${ }^{\circledR}$ (Orlando, FL) patty maker, resulting in a patty $1 \mathrm{~cm}$ thick. Patties from each experimental batch were frozen at $-20^{\circ} \mathrm{C}$ prior to their use in the sensory tests.

Table 1. Formulation of experimental batches.

\begin{tabular}{cccccccccc}
\hline $\begin{array}{c}\text { Phosphate } \\
(\mathbf{\%})\end{array}$ & $\begin{array}{c}\text { Shiitake } \\
\mathbf{( \% )}\end{array}$ & $\begin{array}{c}\text { Pork } \\
(\mathbf{g})\end{array}$ & $\begin{array}{c}\text { Onion } \\
(\mathbf{g})\end{array}$ & $\begin{array}{c}\text { Salt } \\
\mathbf{( g )}\end{array}$ & $\begin{array}{c}\text { Black } \\
\text { Pepper }(\mathbf{g})\end{array}$ & $\begin{array}{c}\text { Garlic } \\
\text { Powder }(\mathbf{g})\end{array}$ & $\begin{array}{c}\text { Water } \\
(\mathbf{m L})\end{array}$ & $\begin{array}{c}\text { Phosphate } \\
(\mathbf{g})\end{array}$ & $\begin{array}{c}\text { Shiitake } \\
\text { Powder }(\mathbf{g})\end{array}$ \\
\hline $0 \%$ & $0 \%$ & 800 & 80 & 8 & 1.6 & 0.8 & 48 & 0 & 0 \\
$0 \%$ & $2 \%$ & 800 & 80 & 8 & 1.6 & 0.8 & 48 & 0 & 16 \\
$0 \%$ & $4 \%$ & 800 & 80 & 8 & 1.6 & 0.8 & 48 & 0 & 32 \\
$0 \%$ & $6 \%$ & 800 & 80 & 8 & 1.6 & 0.8 & 48 & 0 & 48 \\
$0.5 \%$ & $0 \%$ & 800 & 80 & 8 & 1.6 & 0.8 & 48 & 4 & 0 \\
$0.5 \%$ & $2 \%$ & 800 & 80 & 8 & 1.6 & 0.8 & 48 & 4 & 16 \\
$0.5 \%$ & $4 \%$ & 800 & 80 & 8 & 1.6 & 0.8 & 48 & 4 & 32 \\
$0.5 \%$ & $6 \%$ & 800 & 80 & 8 & 1.6 & 0.8 & 48 & 4 & 48 \\
\hline
\end{tabular}

\subsection{Cooked Sample Preparation}

Before cooking, patties were thawed overnight in a refrigerator at $4{ }^{\circ} \mathrm{C}$. Each $80 \mathrm{~g}$ pork patty was cooked in a $204{ }^{\circ} \mathrm{C}$ convection oven until the internal meat temperature reached $74{ }^{\circ} \mathrm{C}$ (approximately $16 \mathrm{~min}$ ). Trays of patties were rotated half-way through the cooking process to help ensure that heating was consistent among the patties. For stored samples, cooked pork patties with and without STP and/or SM were wrapped in aluminum foil and stored for 48 or $96 \mathrm{~h}$ at $4{ }^{\circ} \mathrm{C}$ in a commercial refrigerator. For serving, patties were unwrapped and reheated in a microwave oven with a rotating tray before testing by the panel.

\subsection{Panelists}

Five professionally trained panelists (all female) from the Center for Sensory Analysis and Consumer Behavior, Kansas State University, Manhattan, KS comprised the descriptive sensory panel for this study. The panelists had completed $120 \mathrm{~h}$ of training on a broad range of products in all aspects of descriptive sensory techniques, including attribute identification and scaling. Panelists also had more than $1000 \mathrm{~h}$ of experience in general sensory testing for a wide variety of foods, including meat products. Panelists were required to participate in periodic revalidation and retraining during their tenure in sensory analysis testing. Such numbers of highly trained panelists have been shown to be able to discriminate among samples better than larger panels of less trained panelists [40-42]. Similar panels have been used for other recent studies [43-45].

\subsection{Sample Serving}

Patties were cut crosswise into four equal pieces and served on a 6 inch foam plate resting on a warmed brick, to keep the samples at the proper temperature. All samples were assigned three-digit codes, and separate codes were used for lexicon development and actual testing. Eight pork patties, control and with combinations of SM and STP, both fresh and stored were examined during the orientation sessions to develop a lexicon (terminology, definitions, and references) for describing the texture and flavor characteristics. For actual testing, eight sessions for each storage period were held in random order for sample evaluation. During one session, a sample, labeled with a three-digit random number, was served to the panel. After $20 \mathrm{~min}$, another sample of the same product variation was provided to the panel to ensure that samples were evaluated while warm. This re-serving of the samples was continued until the panel had completed their consensus evaluation (three samples of the same variation were usually served in a session, but occasionally only two, or up to four samples were needed). Individual panelists evaluated the intensity of each attribute using the lexicon and ballot developed in the orientation sessions. Intensities were scored on a 0- (none) to 15- (extremely strong) point scale divided into half-point increments. Scores lower than 5 were considered low, scores 
of 5 to 10 were considered moderate, and scores higher than 10 were considered high in intensity on this scale. Deionized water, unsalted crackers, carrots, and Lipton ${ }^{\circledR}$ tea were provided to cleanse the palate during testing. Hot Lipton ${ }^{\circledR}$ tea was prepared according to the directions on the package and was used because the warm liquid and flavor of the tea appeared to remove and neutralize the fatty, soapy flavor sometimes remaining in the mouth between samples.

\subsection{Lexicon Development}

The lexicon development method is a generalized consensus method [46] adapted from the profile method of flavor analysis [47]. Vocabulary differences were discussed, and agreement was reached on attributes, definitions, and references. The use of consensus for vocabulary development is important to ensure that each panelist understands and can agree on the terminology used, as well as the intensities associated with each reference for the attribute.

\subsection{Sample Evaluation}

For testing, samples were cooked and stored, if appropriate, and served to the panelists, one sample variable per session. Panelists were not told whether they were evaluating any of the same samples used in orientation. The same consensus approach was used as during the orientation and lexicon development phase. Consensus evaluation during testing is an effective way to ensure that key attributes, such as storage attributes or ones that have not be apparent in samples during lexicon development, can easily be added and scored consistently by the panelists [46] and has been used effectively for various products in published studies for many years [48-54]. When the panelists reached consensus on the attributes and intensities noted in that sample, testing was completed for that sample. The profile for the fresh control sample with no added phosphate was determined first (requiring four $1 \mathrm{~h}$ sessions) by the panel. Other samples were served on successive days in random order, and their profiles determined.

\subsection{Data Analysis}

Statistical analysis by ANOVA or other methods used to differentiate "means" is inappropriate for flavor profile data because all panelists consent to a single-intensity value (consensus value), resulting in no variance [46]. By definition, differences in scores, which have no variance because they are consensus scores, are different from each other. In practicality, many users of consensus methods use a difference of 1 point as showing an important difference between two samples.

The data from consensus profiles can be, and was used in a Principle Components Analysis (PCA) in SAS ${ }^{\circledR}$ version 9 (SAS Institute, Cary, NC, USA) to "map" the products and attributes for comparison.

\section{Results and Discussion}

\subsection{Lexicon}

The final lexicon for describing texture and flavor characteristics of pork patties is provided in Table 2. All 20 attributes were used to identify characteristics in several variations of patties. The terms are similar to those used by other authors for pork [3-5] and for samples with added phosphates [25,27], although the terminology used in this study tends to be more detailed. 
Table 2. Terms, definitions, references, and intensities for describing texture and flavor characteristics of pork patties.

\begin{tabular}{|c|c|c|}
\hline Attribute & Definition & Reference $^{a}$ and Intensity ${ }^{b}$ \\
\hline \multicolumn{3}{|l|}{ Texture } \\
\hline Juiciness & $\begin{array}{l}\text { The amount of liquid expressed from the sample } \\
\text { during the fourth chew. }\end{array}$ & Hormel Cure 81 Ham $=5.0$ \\
\hline Toughness & $\begin{array}{l}\text { Degree of force required breaking through the } \\
\text { surface of the sample with the molars. } \\
\text { (Low to high) }\end{array}$ & Hormel Cure 81 Ham $=9.0$ \\
\hline Rubbery & $\begin{array}{l}\text { The perception by which individual meat pieces } \\
\text { bounce away from molars during mastication. }\end{array}$ & Oscar Mayer Fat Free Wiener $=7.5$ \\
\hline Mealy & $\begin{array}{l}\text { The perception of fine, soft particles distributed } \\
\text { within the product. }\end{array}$ & Beef Liver $=10.0$ \\
\hline \multicolumn{3}{|l|}{ Flavor } \\
\hline Pork ID & $\begin{array}{l}\text { Meat aromatics that can be specifically identified } \\
\text { as cooked pork. }\end{array}$ & Pork Patty = 9.0 (flavor) \\
\hline Meatiness & $\begin{array}{l}\text { The perception of aromatics associated with } \\
\text { meat products. }\end{array}$ & Pork Patty = 10.0 (flavor) \\
\hline Mushroom & $\begin{array}{l}\text { Aromatics associated with dried shitake } \\
\text { mushrooms such as brown, musty/earthy, and } \\
\text { dried mustard-like. }\end{array}$ & $\begin{array}{c}\text { Shitake Mushroom Powder in water }=7.5 \\
\text { (flavor) }\end{array}$ \\
\hline \multirow{2}{*}{ Onion } & \multirow{2}{*}{$\begin{array}{l}\text { The aromatics commonly associated with onion } \\
\text { characterized as sweet and slightly pungent. }\end{array}$} & Chopped Fresh White Onion $=7.0$ (flavor) \\
\hline & & McCormick Onion Powder $=9.0($ aroma $)$ \\
\hline Garlic & Aromatics associated with garlic. & McCormick Garlic Powder = 9.5 (aroma) \\
\hline Black Pepper & $\begin{array}{l}\text { Spicy, pungent, musty and woody aromatics } \\
\text { characteristic of ground black pepper. }\end{array}$ & $\begin{array}{l}\text { McCormick Ground Black Pepper }=13.0 \\
\text { (aroma) }\end{array}$ \\
\hline Soapy & An aromatic associated with hand soap. & $0.25 \%$ solution of Ivory bar soap $=2.0$ \\
\hline Chemical & $\begin{array}{l}\text { Aromatic associated with garden hose, hot Teflon } \\
\text { pan, plastic packaging. }\end{array}$ & $\begin{array}{l}\text { Lightly burnt (Singed) plastic in covered } \\
\text { beaker }=13.0\end{array}$ \\
\hline Animal Hair & $\begin{array}{l}\text { The aromatic perceived when raw wool is } \\
\text { saturated with water (not including soap, solvent, } \\
\text { or lanolin aromatics). }\end{array}$ & Wool in water $=9.5$ (aroma) \\
\hline \multirow{3}{*}{ Fat } & \multirow{3}{*}{$\begin{array}{l}\text { Flavor associated with fat. Ranging from light } \\
\text { to heavy. }\end{array}$} & Wesson Vegetable Oil = 7.0 (aroma) \\
\hline & & Pork Patty $=7.5$ (flavor) \\
\hline & & Wesson Vegetable Oil = 10.0 (flavor) \\
\hline \multirow{4}{*}{ Salty } & \multirow{4}{*}{$\begin{array}{l}\text { A fundamental taste sensation of which sodium } \\
\text { chloride in water is typical. }\end{array}$} & $0.15 \%$ Sodium Chloride Solution $=1.5$ \\
\hline & & $0.2 \%$ Sodium Chloride Solution $=2.5$ \\
\hline & & $0.25 \%$ Sodium Chloride Solution $=3.5$ \\
\hline & & $0.35 \%$ Sodium Chloride Solution $=5.0$ \\
\hline \multirow{2}{*}{ Sour } & \multirow{2}{*}{$\begin{array}{l}\text { A fundamental taste sensation of which citric acid } \\
\text { in water is typical. }\end{array}$} & $0.015 \%$ citric acid solution $=1.5$ \\
\hline & & $0.025 \%$ citric acid solution $=2.5$ \\
\hline \multirow{3}{*}{ Bitter } & \multirow{3}{*}{$\begin{array}{l}\text { The fundamental taste sensation of which caffeine } \\
\text { in water is typical. }\end{array}$} & $0.01 \%$ caffeine solution $=2.0$ \\
\hline & & $0.02 \%$ caffeine solution $=3.5$ \\
\hline & & $0.035 \%$ caffeine solution $=5.0$ \\
\hline
\end{tabular}

\begin{tabular}{ccc}
\hline Mouthfeel & & \\
\hline Slick & $\begin{array}{c}\text { A feeling factor (possibly textural) that gives the } \\
\text { impression of smoothing the surfaces of the } \\
\text { mouth, especially the tongue. }\end{array}$ & Quaker Quick Oats Oatmeal $=12.0$ \\
\hline Astringent & $\begin{array}{c}\text { The chemical feeling factor on the tongue or oral } \\
\text { cavity that can be described as puckering or dry. }\end{array}$ & $0.03 \%$ Alum Solution $=1.5$ \\
\cline { 3 - 3 } & & $0.05 \%$ Alum Solution $=2.5$
\end{tabular}

\footnotetext{
${ }^{a}$ Generally, references were served at room temperature; ${ }^{b}$ Intensities based on a 0 (none) to 15 (extremely strong) scale.
} 


\subsection{Fresh Patties: Texture and Flavor Results}

Intensities for the texture and flavor, including mouthfeel attributes (Table 3), show that differences were obtained by the panel, differentiating among cooked pork patties with or without $0.5 \%$ STP and with either $0 \%, 2 \%, 4 \%$, or $6 \%$ SM.

Intensities for the texture and flavor, including mouthfeel attributes (Table 3), show considerable differences in samples for many attributes. For texture, samples containing SM and no STP generally had higher juiciness, were less rubbery, and were mealier than samples with STP. Regardless of the amount of SM added, the addition of STP resulted in samples without any mealy character. Juiciness appeared to decline in samples with both STP and SM added at higher amounts, suggesting that the combination of the two ingredients either bind moisture so much that it is not released when chewed, or that those samples had a high level of cooking loss. Unfortunately, neither of those physical measures were taken in this study. Other researchers have shown that STP added to turkey patties increased consumer perception of juiciness and decreased firmness.

Examination of flavor profiles for the different types of pork patties showed that pork patties without STP were rated higher for pork ID, meatiness, onion, garlic, pepper, and fatty character. Samples containing $0.5 \%$ STP generally had higher ratings for soapy, salty, and sour attributes. The soapy attribute, which has been noted by other researchers [22,25,27], was at a low intensity, but showed a trend of increasing intensity in STP containing samples when higher levels of SM were added. Soapiness is often considered an undesirable flavor characteristic in pork patties, and appeared to be related to the presence of STP. However, prior research has shown that off-flavors from STP are inconsistently perceived by consumers [26] in chicken patties. The addition of STP increased acceptance of pork patties regardless of addition of SM for Korean consumers, and increased acceptance among US consumers, but only when SM was not present or at low levels [20]. In addition, recent research [55-57] has shown that consumers want more "natural" foods, and the use of ingredients with "chemical-sounding names" (in this case, sodium tripolyphosphate) result in reduced perceptions of naturalness. Morse [58] reported an unacceptable soapy flavor when STP was used in meat. A mouthfeel designated as "soapy" was found in STP-containing samples, and might be considered an off-flavor. Hargett and others [59] found that an increase in the sourness of frankfurters was correlated with the use of sodium acid pyrophosphate. An astringent attribute was noted to be an important contributor to the overall flavor of pork. This astringent attribute, as well as the basic tastes, has too been found in the evaluation of other muscle foods [60,61].

The addition of SM powder alone slightly decreased pork ID and increased mushroom character, although the meaty flavor remained at a moderate level unless $6 \% \mathrm{SM}$ was added, at which point the samples had less meaty flavor than the control without STP or SM. The addition of $6 \%$ SM also increased the chemical flavor regardless of whether STP was added. The addition of either SM or STP seemed to mute the intensity of other additive flavors, such as onion, garlic, and pepper. High levels of SM $(6 \%)$ combined with $0.5 \%$ STP produced the highest intensity ratings for the attributes soapy, chemical, bitter, and animal hair, suggesting that $6 \% \mathrm{SM}$ is too high a percentage for addition to pork patties. Other research has shown that addition of $6 \%$ SM with STP was disliked by US consumers, although it was liked by Korean consumers [20]. 
Table 3. Flavor and texture profile scores for pork patties with varied percentages of shiitake mushroom powder with and without phosphate.

\begin{tabular}{ccccccccc}
\hline & \multicolumn{7}{c}{ Sodium Tripolyphosphate (STP) } \\
\cline { 2 - 8 } & \multicolumn{7}{c}{$\mathbf{0} \%$} & \multicolumn{3}{c}{$\mathbf{0 . 5 0 \%}$} \\
\hline Shiitake & $\mathbf{0 \%}$ & $\mathbf{2 \%}$ & $\mathbf{4 \%}$ & $\mathbf{6 \%}$ & $\mathbf{0 \%}$ & $\mathbf{2 \%}$ & $\mathbf{4 \%}$ & $\mathbf{6 \%}$ \\
\hline Texture & & & & & & & & \\
\hline Juiciness & 6.5 & 7.0 & 8.0 & 7.5 & 7.0 & 8.0 & 6.0 & 6.5 \\
Toughness & 9.0 & 5.0 & 6.0 & 3.5 & 6.0 & 8.0 & 5.5 & 6.5 \\
Rubbery & 5.0 & 2.0 & 4.0 & 0.0 & 6.5 & 6.0 & 5.5 & 5.0 \\
Mealy & 0.0 & 3.0 & 3.0 & 4.0 & 0.0 & 0.0 & 0.0 & 0.0 \\
\hline Flavor & & & & & & & & \\
\hline Pork ID & 7.0 & 5.5 & 5.0 & 3.0 & 4.5 & 5.5 & 4.0 & 3.5 \\
Meatiness & 9.0 & 8.0 & 8.0 & 4.5 & 7.5 & 9.0 & 8.0 & 6.5 \\
Mushroom & 0.0 & 2.0 & 5.0 & 4.0 & 2.0 & 2.5 & 4.0 & 5.0 \\
Onion & 5.0 & 3.0 & 3.5 & 2.5 & 2.0 & 2.5 & 2.0 & 1.0 \\
Garlic & 2.5 & 1.5 & 2.5 & 0.0 & 1.0 & 2.0 & 1.5 & 1.0 \\
Black Pepper & 3.5 & 2.5 & 4.0 & 2.0 & 2.0 & 3.5 & 2.5 & 3.0 \\
Heat Burn & 0.0 & 1.5 & 1.5 & 0.0 & 1.5 & 2.0 & 0.0 & 1.5 \\
Soapy & 0.0 & 0.0 & 2.0 & 0.0 & 2.0 & 2.0 & 2.5 & 3.0 \\
Chemical & 0.0 & 2.0 & 0.0 & 2.0 & 0.0 & 0.0 & 0.0 & 4.0 \\
Fat & 5.0 & 5.0 & 4.0 & 4.5 & 4.0 & 4.0 & 4.0 & 4.0 \\
Salty & 3.0 & 3.0 & 2.5 & 3.0 & 3.0 & 3.5 & 3.0 & 3.5 \\
Sour & 1.5 & 1.5 & 1.5 & 2.0 & 2.5 & 2.0 & 2.0 & 2.5 \\
Bitter & 2.0 & 2.0 & 2.0 & 2.0 & 2.0 & 2.0 & 2.0 & 3.0 \\
\hline Mouthfeel & & & & & & & & \\
\hline Slick & 0.0 & 0.0 & 1.5 & 2.0 & 0.0 & 0.0 & 0.0 & 0.0 \\
Astringent & 0.0 & 1.5 & 0.0 & 1.5 & 1.5 & 2.0 & 2.0 & 2.0 \\
\hline & & & & & & & &
\end{tabular}

\subsection{Stored Patties: Texture and Flavor Results}

Sensory data for patties that had been stored for $48 \mathrm{~h}$ or $96 \mathrm{~h}$ after cooking are presented in Tables 4 and 5, respectively. Storage of cooked pork patties for $48 \mathrm{~h}$ and $96 \mathrm{~h}$, with STP, increased the perception of astringency (Tables 4 and 5) compared to fresh samples. Storage for $48 \mathrm{~h}$ led to increased intensity ratings for soapiness and bitterness, and reduced intensity ratings for fat, pork ID, meatiness, and brown/roasted flavors (Table 4). Addition of SM alone and subsequent $48 \mathrm{~h}$ storage produced increases in sourness, meatiness, protein, and brown/roasted attributes, but reductions in pork ID. Addition of both SM and STP followed by $48 \mathrm{~h}$ storage yielded increases in salty, meaty, and brown/roasted flavors and reductions in protein and bitter flavors. Storage of patties, regardless of addition of SM or STP, decreased juiciness, and produced a warmed-over flavor (WOF), an unspecified protein note, and a brown/roasted character that might be associated with Maillard browning occurring during the reheating process in samples with less moisture.

After $96 \mathrm{~h}$ of storage, patties with SM alone had reduced intensities for most attributes, with the exception of fat perception and an increase in WOF. Use of both SM and STP, followed by $96 \mathrm{~h}$ storage, produced increases in ratings for salty, sour, brown/roasted, and pork ID; only occasional decreases in ratings were noted at this storage time compared to $48 \mathrm{~h}$. 
Table 4. Flavor and texture profile scores for pork patties with varied percentages of shiitake mushroom powder with and without phosphate, and with $48 \mathrm{~h}$ storage.

\begin{tabular}{|c|c|c|c|c|c|c|c|c|}
\hline \multirow[b]{3}{*}{ Shiitake } & \multicolumn{8}{|c|}{ Sodium Tripolyphosphate (STP) } \\
\hline & \multicolumn{4}{|c|}{$0 \%$} & \multicolumn{4}{|c|}{$0.50 \%$} \\
\hline & $0 \%$ & $2 \%$ & $4 \%$ & $6 \%$ & $0 \%$ & $2 \%$ & $4 \%$ & $6 \%$ \\
\hline \multicolumn{9}{|l|}{ Texture } \\
\hline Juiciness & 4.0 & 5.0 & 4.5 & 4.5 & 6.0 & 6.0 & 6.0 & 5.5 \\
\hline Toughness & 7.0 & 7.0 & 6.5 & 5.0 & 6.5 & 5.5 & 7.0 & 6.0 \\
\hline Rubbery & 2.0 & 3.5 & 2.5 & 2.0 & 6.0 & 5.5 & 6.0 & 5.0 \\
\hline Mealy & 2.5 & 2.5 & 2.5 & 5.0 & 0.0 & 0.0 & 0.0 & 2.0 \\
\hline \multicolumn{9}{|l|}{ Flavor } \\
\hline Pork ID & 6.5 & 6.0 & 5.0 & 3.0 & 5.0 & 4.5 & 5.5 & 4.5 \\
\hline Meatiness & 9.0 & 9.0 & 8.0 & 6.0 & 7.0 & 8.5 & 9.0 & 7.5 \\
\hline Mushroom & 0.0 & 2.0 & 3.0 & 1.5 & 0.0 & 3.0 & 3.5 & 3.5 \\
\hline Onion & 2.5 & 2.5 & 2.5 & 3.0 & 2.5 & 2.0 & 2.0 & 2.0 \\
\hline Garlic & 1.5 & 2.0 & 2.0 & 1.5 & 1.5 & 1.5 & 1.5 & 1.5 \\
\hline Black Pepper & 3.0 & 2.0 & 3.5 & 3.0 & 3.0 & 2.5 & 3.0 & 1.5 \\
\hline Heat Burn & 1.0 & 0.0 & 2.0 & 1.5 & 0.0 & 0.0 & 2.0 & 0.0 \\
\hline Soapy & 0.0 & 0.0 & 3.0 & 1.5 & 0 & 1.0 & 2.5 & 2.0 \\
\hline Chemical & 0.0 & 0.0 & 0.0 & 0.0 & 0.0 & 0.0 & 2.0 & 2.0 \\
\hline Fat & 4.0 & 3.5 & 3.5 & 3.5 & 3.5 & 3.5 & 4.0 & 4.0 \\
\hline Protein & 0.0 & 1.0 & 2.0 & 4.0 & 4.0 & 2.5 & 2.5 & 2.5 \\
\hline Brown/Roasted & 5.5 & 4.5 & 5.0 & 5.0 & 4.0 & 4.5 & 4.5 & 4.5 \\
\hline Warmed-Over Flavor & 2.0 & 1.5 & 3.0 & 2.5 & 1.5 & 1.5 & 1.5 & 1.5 \\
\hline Salty & 3.0 & 3.0 & 3.0 & 3.5 & 3.0 & 3.5 & 3.5 & 3.5 \\
\hline Sour & 2.0 & 2.0 & 2.5 & 2.0 & 2.0 & 2.0 & 2.0 & 2.5 \\
\hline Bitter & 2.0 & 1.5 & 2.0 & 2.0 & 2.5 & 2.0 & 2.0 & 2.0 \\
\hline \multicolumn{9}{|l|}{ Mouthfeel } \\
\hline Slick & 0.0 & 0.0 & 0.0 & 0.0 & 0.0 & 0.0 & 1.0 & 0.0 \\
\hline Astringent & 1.5 & 0.0 & 1.5 & 2.0 & 1.5 & 2.5 & 3.0 & 1.5 \\
\hline
\end{tabular}

Table 5. Flavor and texture profile scores for pork patties with varied percentages of shiitake mushroom powder with and without phosphate, and with $96 \mathrm{~h}$ storage.

\begin{tabular}{ccccccccc}
\hline & \multicolumn{7}{c}{ Sodium Tripolyphosphate (STP) } \\
\cline { 2 - 9 } & \multicolumn{7}{c}{$\mathbf{0 \%}$} & \multicolumn{5}{c}{$\mathbf{0 . 5 0 \%}$} \\
\hline Shiitake & $\mathbf{0 \%}$ & $\mathbf{2 \%}$ & $\mathbf{4 \%}$ & $\mathbf{6 \%}$ & $\mathbf{0 \%}$ & $\mathbf{2 \%}$ & $\mathbf{4 \%}$ & $\mathbf{6 \%}$ \\
\hline Texture & & & & & & & & \\
\hline Juiciness & 3.0 & 5.0 & 5.0 & 6.5 & 6.0 & 7.0 & 6.0 & 6.5 \\
Toughness & 9.5 & 6.0 & 5.0 & 5.0 & 6.5 & 7.0 & 6.5 & 8.0 \\
Rubberiness & 4.0 & 2.5 & 2.0 & 1.0 & 6.0 & 5.5 & 5.5 & 6.0 \\
Mealy & 2.5 & 3.0 & 3.5 & 4.0 & 0.0 & 0.0 & 0.0 & 0.0 \\
\hline Flavor & & & & & & & & \\
\hline Pork ID & 4.0 & 4.5 & 4.0 & 4.5 & 5.5 & 6.5 & 5.5 & 3.5 \\
Meatiness & 7.5 & 7.5 & 5.5 & 5.5 & 9.0 & 8.0 & 9.0 & 7.0 \\
Mushroom & 0.0 & 3.5 & 4.0 & 3.5 & 0.0 & 0.0 & 1.5 & 2.0 \\
Onion & 3.0 & 25 & 2.5 & 2.0 & 3.0 & 2.0 & 3.5 & 2.0 \\
Garlic & 2.5 & 1.5 & 2.0 & 1.5 & 2.5 & 1.5 & 1.5 & 1.5 \\
Black Pepper & 3.0 & 3.0 & 2.5 & 2.0 & 2.0 & 2.0 & 2.0 & 1.5 \\
Heat Burn & 0.0 & 1.5 & 0.0 & 0.0 & 1.0 & 0.0 & 0.0 & 0.0 \\
Soapy & 0.0 & 2.5 & 2.0 & 2.0 & 1.5 & 2.0 & 1.5 & 2.5 \\
Chemical & 0.0 & 0.0 & 0.0 & 0.0 & 0.0 & 0.0 & 0.0 & 2.0 \\
Fat & 3.0 & 3.5 & 4.0 & 4.0 & 4.0 & 4.0 & 4.5 & 4.0 \\
\hline
\end{tabular}


Table 5. Cont.

\begin{tabular}{ccccccccc}
\hline & \multicolumn{7}{c}{ Sodium Tripolyphosphate (STP) } \\
\cline { 2 - 9 } & \multicolumn{7}{c}{$\mathbf{0 \%}$} & \multicolumn{5}{c}{$\mathbf{0 . 5 0 \%}$} \\
\hline Shiitake & $\mathbf{0 \%}$ & $\mathbf{2 \%}$ & $\mathbf{4 \%}$ & $\mathbf{6 \%}$ & $\mathbf{0 \%}$ & $\mathbf{2 \%}$ & $\mathbf{4 \%}$ & $\mathbf{6 \%}$ \\
\hline Flavor & & & & & & & \\
Protein & 3.0 & 3.0 & 3.0 & 4.0 & 1.0 & 2.0 & 2.0 & 3.5 \\
Brown/Roasted & 4.0 & 5.0 & 5.0 & 4.5 & 5.0 & 5.5 & 5.5 & 5.0 \\
Warmed-Over Flavor & 3.0 & 2.5 & 2.5 & 2.5 & 3.0 & 2.5 & 2.0 & 3.0 \\
Rancid & 0.0 & 0.0 & 0.0 & 0.0 & 0.0 & 2.0 & 0.0 & 0.0 \\
Salty & 2.5 & 3.5 & 3.0 & 3.5 & 3.5 & 3.5 & 3.5 & 3.0 \\
Sour & 1.5 & 2.5 & 1.5 & 2.0 & 2.5 & 2.0 & 2.5 & 2.0 \\
Bitter & 2.0 & 2.0 & 2.0 & 2.0 & 2.0 & 2.0 & 2.0 & 2.0 \\
\hline Mouthfeel & & & & & & & & \\
\hline Slick & 0.0 & 0.0 & 0.0 & 0.0 & 0.0 & 0.0 & 2.0 & 0.0 \\
Astringent & 1.5 & 1.5 & 1.5 & 1.5 & 3.0 & 2.5 & 3.0 & 3.0 \\
\hline
\end{tabular}

\subsection{Principal Component Maps (Biplots) of Sensory Data and Pork Patty Variations}

The sensory maps (Figures 1 and 2) clearly show the impact of the addition of SM and STP, as well as age on the samples. Although it is typical to show only the first and second principal components (PCs), the third and fourth PCs account for approximately 25 percent of the variation. Other authors have noted that using only a single map showing two dimensions can be problematic because the mapping procedure is based on overall data and can distort interpretation without careful review of other data sources, including additional PCs and the original data [62,63].

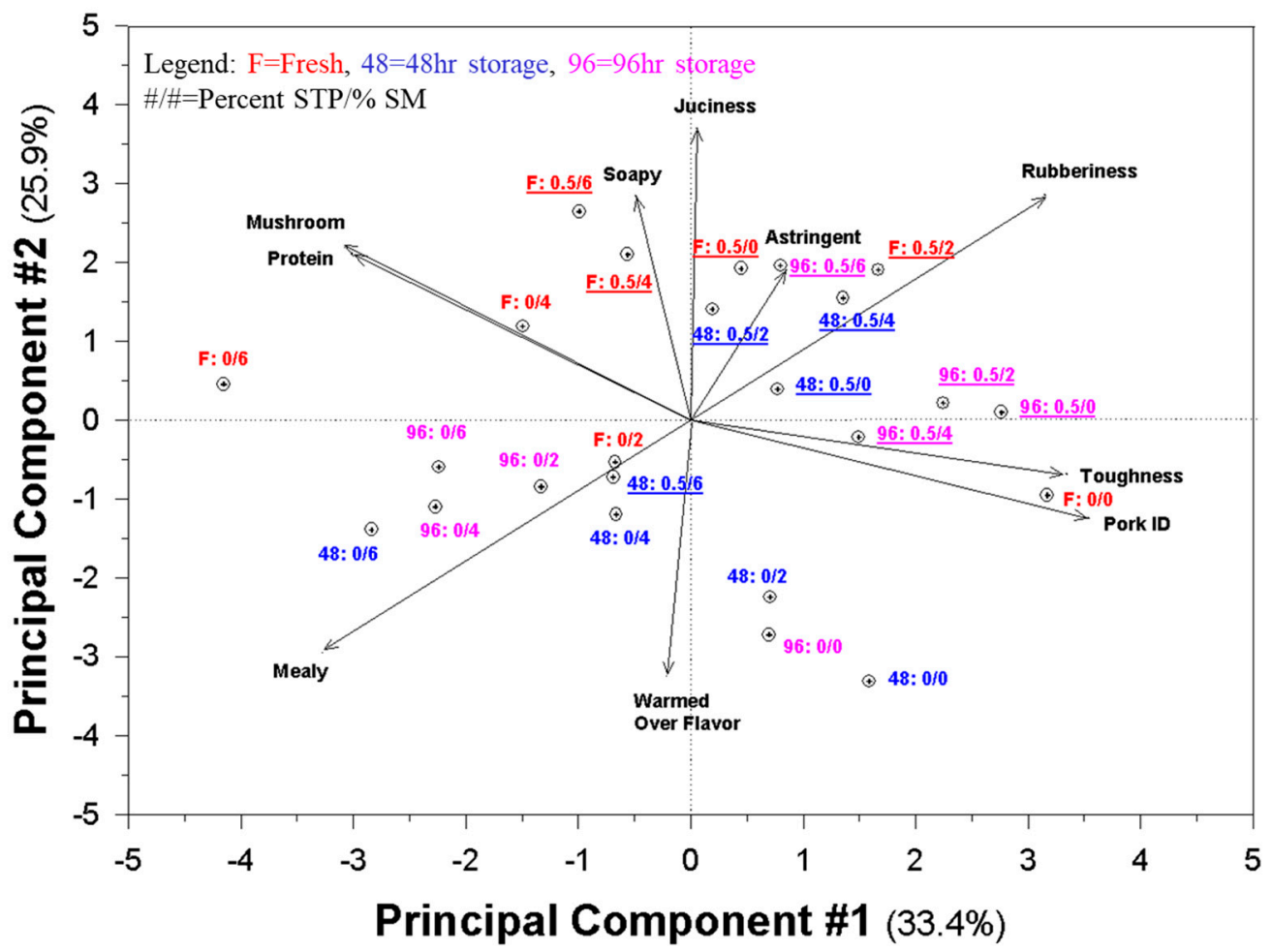

Figure 1. Principal component analysis (PCA) plot relating samples varying in amount of shitake mushroom powder and sodium tripolyphosphate to attribute intensities given by the descriptive panel. 


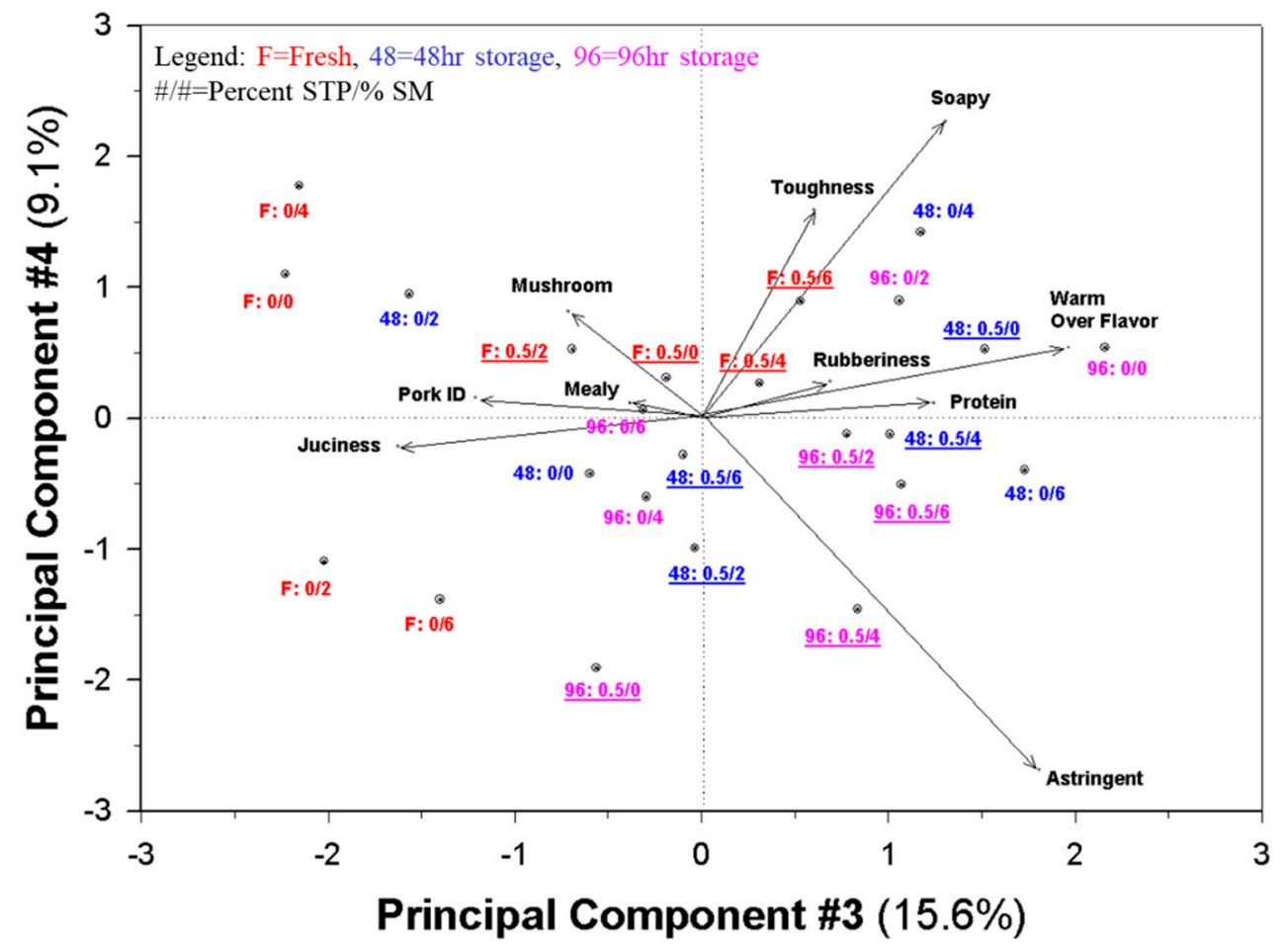

Figure 2. Principal component analysis (PCA) plot relating samples varying in amount of shitake mushroom powder and sodium tripolyphosphate to attribute intensities given by the descriptive panel.

In this case, in Figure 1 it can clearly be noted that the addition of SM increases mushroom, protein, and meaty flavors and reduces the specific pork ID character in the patties. Addition of STP increased rubberiness and astringency. Toughness, pork ID, and juiciness also tended to increase with the addition of STP. However, Figure 2 shows that the increase in the general protein flavor is dependent on storage; fresh samples did not show that character.

Both Figures 1 and 2 show the interaction of the addition of SM, STP, and time. All samples of any one type tend to be scattered into at least two quadrants of the maps, which suggests that the one variable is dependent on the level of at least one other variable. However, the maps still show a rather cohesive picture that differentiates fresh from stored samples, samples with and without SM, and those with and without STP.

One obvious limitation of this study is that no consumer data was collected on stored samples, although prior consumer studies were published on similar fresh samples [20]. However, no comparison can be made between this study and prior consumer studies because of the complexity of the consumer response and limitations on the number of samples.

\section{Conclusions}

In this study, 19 flavor and texture attributes (four textures, 13 flavors, and two mouthfeel attributes) were identified in pork patties with added SM and STP. Those attributes include ones related to fresh pork flavor, stored pork flavor, and the characteristics imparted by STP and SM when added to pork. Specific lexicons are valuable for use by future researchers to understand additional issues associated with such ingredients in products.

Shiitake mushroom powder alone (i.e., without added phosphate) increased the juiciness and decreased the toughness and rubberiness of the pork. There was no change in pork ID with added SM, although overall meatiness decreased with a concomitant increase in mushroom flavor. Mushroom flavor could include the impact of the umami character in mushrooms. SM also slightly increased the soapy character of the patties. 
As expected, pork patties with added STP alone were less tough and had much more rubberiness than those without STP or SM added. STP also decreased pork ID, meatiness, and increased soapy character and astringency.

Increases in juiciness, decreases in toughness and rubberiness, along with higher levels of pork ID, meatiness, and a lack of off-notes, such as soapy and astringency, are generally positive things for meat products. The impact of mushroom flavor notes is dependent on culture [20].

As expected, storage did not result in any potentially positive changes in pork patties, although it must be stated again that consumer studies were not conducted on stored samples and consumers could respond differently than expectations. Storage for 48 or $96 \mathrm{~h}$ decreased juiciness regardless of whether SM, STP, or both were added. Mealiness tended to increase over time with or without SM, but did not develop in those products containing STP. Many flavor attributes, such as the spice/seasoning notes and basic tastes, changed little over time regardless of additives, suggesting that those flavors are unaffected by the storage process. In addition, there was little change in samples which were fresh or had been in $48 \mathrm{~h}$ of storage, with the exception that WOF appeared as expected. Unfortunately, neither SM nor STP appeared to reduce WOF. At $96 \mathrm{~h}$ of storage, pork ID and meatiness tended to slightly decrease with added SM, and pork ID slightly increased with STP. In addition, a rancid note appeared in one sample containing STP. Astringency was increased slightly at $96 \mathrm{~h}$ with added STP, and this was not affected when SM powder was added to those samples.

Overall, SM and STP impacted both the flavor and texture of the pork patties and did little to mitigate storage effects. The presence of SM increased the perception of mealiness in pork patties and did not seem to consistently enhance the protection from cooking losses and development of WOF gained by the addition of STP. Although STP may contribute to undesirable flavors when added to pork patties, advantages in improved texture and overall acceptability can be gained by the addition of this chemical [64]. The data show that these additives were generally not effective in reducing aspects of stored pork that are considered undesirable (e.g., WOF, rancidity, astringency) by many researchers. Future studies should evaluate individual attributes of pork patties with additives, and how the changes in specific sensory characteristics are different. Understanding specific characteristics will allow researchers to better understand the impacts on consumer acceptance.

Author Contributions: Conceptualization, S.C., E.C.IV; Methodology, S.C., D.H.C.; Validation, S.C., D.H.C.; Formal analysis, S.C., E.C.IV; Investigation, S.C., D.H.C.; Resources, E.C.IV, D.H.C.; Data curation, S.C.; Writing-Original draft preparation, S.C.; Writing-Review and editing, E.C.IV; Supervision, E.C.IV; Project administration, S.C., D.H.C.; Funding acquisition, E.C.IV. All authors have read and agreed to the published version of the manuscript.

Funding: This research is based on work supported by the National Institute of Food and Agriculture, U.S. Department of Agriculture, Hatch under accession number 1016242. This article was supported (in part) by the Non Directed Research Fund, Sunchon National University.

Conflicts of Interest: The authors declare no conflict of interest.

\section{References}

1. Grunert, K.G.; Bredahl, L.K. Consumer perception of meat quality and implications for product development in the meat sector-A review. Meat Sci. 2004, 66, 259-272. [CrossRef]

2. Resano, H.; Perez-Cueto, F.J.A.; de Barcellos, M.D.; Veflen-Olsen, N.; Grunert, K.G.; Verbeke, W. Consumer satisfaction with pork meat and derived products in five European countries. Appetite 2011, 56, 167-170. [CrossRef] [PubMed]

3. Hornstein, I.; Wasserman, A. Sensory characteristics of meat. In The Science of Meat and Meat Products, 2nd ed.; Price, F., Schweiger, B.S., Eds.; Food and Nutrition Press: Westport, CT, USA, 1987; pp. 329-347.

4. Wasserman, A.E. Thermally produced flavor components in the aroma of meat and poultry. J. Agri. Food Chem. 1972, 20, 737-741. [CrossRef]

5. Aaslyng, M.D.; Meinert, L. Meat flavour in pork and beef-From animal to meal. Meat Sci. 2017, 132, $112-117$. [CrossRef] [PubMed]

6. Hong, J.-S.; Lee, K.-R.; Kim, Y.-H.; Kim, D.-H.; Kim, M.-K.; Kim, Y.-S.; Yeo, K.-Y. Volatile Flavor Compounds of Korean shiitake mushroom (Lentinus edodes). Korean J. Food Sci. Technol. 1988, 20, 606-612. 
7. Phat, C.; Moon, B.; Lee, C. Evaluation of umami taste in mushroom extracts by chemical analysis, sensory evaluation, and an electronic tongue system. Food Chem. 2016, 192, 1068-1077. [CrossRef]

8. Dermiki, M.; Phaphensophon, N.; Mottram, D.S.; Methven, L. Contributions of non-volatile and volatile compounds to the umami taste and overall flavour enhancers in cooked minced meat. Food Chem. 2013, 141, 77-83. [CrossRef]

9. Bredahl, L.; Grunert, K.G.; Fertin, C. Relating consumer perceptions of pork quality to physical product characteristics. Food Qual. Pref. 1998, 9, 273-281. [CrossRef]

10. O'Mahony, R.; Cowan, C.; Keane, M. Consumer preferences for pork chops with different levels of intramuscular fat. Food Qual. Pref. 1991, 3, 229-234. [CrossRef]

11. Avinash, J.; Vinay, S.; Jha, K.; Das, D.; Goutham, B.S.; Kumar, G. The unexplored anticaries potential of shiitake mushroom. Pharmac. Rev. 2016, 10, 100-104.

12. Fukushima, M.; Ohashi, T.; Fujiwara, Y.; Sonoyama, K.; Nakano, M. Cholesterol-lowering effects of maitake (Grifola frondosa) fiber, shiitake (Lentinus edodes) fiber, and enokitake (Flammulina velutipes) fiber in rats. Exp. Biol. Med. 2001, 226, 758-765. [CrossRef] [PubMed]

13. Hirasawa, M.; Shouji, N.; Neta, T.; Fukushima, K.; Takada, K. Three kinds of antibacterial substances from Lentinus edodes (Berk.) Sing. (Shiitake, an edible mushroom). Int. J. Antimicrob. Agents 1999, 11, 151-157. [CrossRef]

14. Ng, M.L.; Yap, A.T. Inhibition of human colon carcinoma development by lentinan from shiitake mushrooms (Lentinus edodes). J. Altern. Comp. Med. 2002, 8, 581-589. [CrossRef] [PubMed]

15. Ngai, P.H.K.; Ng, T.B. Lentin, a novel and potent antifungal protein from shitake mushroom with inhibitory effects on activity of human immunodeficiency virus-1 reverse transcriptase and proliferation of leukemia cells. Life Sci. 2003, 73, 3363-3374. [CrossRef]

16. Yamada, T.; Oinuma, T.; Niihashi, M.; Mitsumata, M.; Fujioka, T.; Hasegawa, K.; Nagaoka, H.; Itakura, H. Effects of Lentinus edodes mycelia on Dietary-Induced Atherosclerotic Involvement in Rabbit Aorta. J. Atheros. Thromb. 2002, 3, 149-156. [CrossRef]

17. Lee, K.; Lee, H.; Choi, Y.; Kim, Y.; Jeong, H.S.; Lee, J. Effect of different cooking methods on the true retention of vitamins, minerals, and bioactive compounds in shiitake mushrooms (Lentinula edodes). Food Sci. Tech. Res. 2019, 25, 115-122. [CrossRef]

18. Li, S.; Wang, A.; Liu, L.; Tian, G.; Wei, S.; Xu, F. Evaluation of nutritional values of shiitake mushroom (Lentinus edodes) stipes. J. Food Meas. Charact. 2018, 12, 2012-2019. [CrossRef]

19. Novakovic, S.; Djekic, I.; Klaus, A.; Vunduk, J.; Djordjevic, V.; Tomović, V.; Šojić, B.; Kocić-Tanackov, S.; Lorenzo, J.M.; Barba, F.J.; et al. The effect of Cantharellus cibarius addition on quality characteristics of frankfurter during refrigerated storage. Foods 2019, 8, 635. [CrossRef]

20. Chun, S.S.; Chambers, E., IV; Chambers, D.H. Perception of pork patties with shiitake (Lentinus Edodes P.) mushroom powder and sodium tripolyphosphate as measured by Korean and United States consumers. J. Sens. Stud. 2005, 20, 169-179. [CrossRef]

21. Taylor, J.; Ahmed, I.A.M.; Al-Juhaimi, F.Y.; Bekhit, A.E.-D.A. Consumers' perceptions and sensory properties of beef patty analogues. Foods 2020, 9, 63. [CrossRef]

22. Ellinger, R. Phosphates as Food Ingredients; CRC Press: Boca Raton, FL, USA, 1972.

23. Long, N.H.B.S.; Gál, R.; Buňka, F. Use of phosphates in meat products. Afr. J. Biotechnol. 2011, 10, 19874-19882.

24. Villamonte, G.; Simonin, H.; Duranton, F.; Chéret, R.; De Lamballerie, M. Functionality of pork meat proteins: Impact of sodium chloride and phosphates under high-pressure processing. Innov. Food Sci. Emerg. Technol. 2013, 18, 15-23. [CrossRef]

25. Smith, L.; Simmons, S.; Mckeith, F.; Bechtel, P.; Brady, P. Effects of sodium tripolyphosphate on physical and sensory properties of beef and pork roasts. J. Food Sci. 1984, 49, 1636-1637. [CrossRef]

26. Chambers, L.; Chambers, E., IV; Bowers, J.R. Consumer acceptability of cooked stored ground turkey patties with differing levels of phosphate. J. Food Sci. 1992, 57, 1026-1028. [CrossRef]

27. Chambers, E., IV; Bowers, J.R.; Smith, E.A. Flavor of cooked, ground turkey patties with added sodium tripolyphosphate as perceived by sensory panels with differing phosphate sensitivity. J. Food Sci. 1992, 57, 521-523. [CrossRef]

28. Talavera, M.; Chambers, E., IV. Using sensory sciences helps products succeed. Br. Food J. 2017, 119, $2130-2144$. [CrossRef] 
29. Suwonsichon, S. The importance of sensory lexicons for research and development of food products. Foods 2019, 8, 27. [CrossRef]

30. Yang, J.; Lee, J. Application of sensory descriptive analysis and consumer studies to investigate traditional and authentic foods: A review. Foods 2019, 8, 54. [CrossRef]

31. Szymandera-Buszka, K.; Waszkowiak, K.; Jędrusek-Golińska, A.; Hęś, M. Sensory analysis in assessing the possibility of using ethanol extracts of spices to develop new meat products. Foods 2020, 9, 209. [CrossRef]

32. Maughan, C.; Martini, S. Identification and quantification of flavor attributes present in chicken, lamb, pork, beef, and turkey. J. Food Sci. 2012, 77, S115-S121. [CrossRef]

33. Akcan, T.; Estevez, M.; Rico, S.; Ventanas, S.; Morcuende, D. Hawberry (Crataegus monogyna Jaqc.) extracts inhibit lipid oxidation and improve consumer liking of ready-to-eat (RTE) pork patties. J. Food Sci. Tech. 2017, 54, 1248-1255.

34. Zang, M.; Wang, L.; Zhang, Z.; Zhang, K.; Li, D.; Li, Z.; Wang, S.; Chen, H. Changes in flavor compound profiles of precooked pork after reheating (warmed-over flavour) using gas chromatography-olfactometry-mass spectrometry with chromatographic feature extraction. Int. J. Food Sci. Tech. 2020, 55, 978-987. [CrossRef]

35. Ferreira, V.C.S.; Morcuende, D.; Madruga, M.S.; Hernández-López, S.H.; Silva, F.A.; Ventanas, S.; Estévez, M. Effect of pre-cooking methods on the chemical and sensory deterioration of ready-to-eat chicken patties during chilled storage and microwave reheating. J. Food Sci. Tech. 2016, 53, 2760-2769. [CrossRef] [PubMed]

36. Choe, J.; Kim, Y.H.B.; Kim, H.-Y.; Kim, C.-J. Evaluations of physicochemical and anti-oxidant properties of powdered leaves from lotus, shepherd's purse and goldenrod in restructured duck/pork patties. J. Food Sci. Tech. 2017, 54, 2494-2502. [CrossRef] [PubMed]

37. Nitha, B.; Smina, T.P.; Janardhanan, R.; Janardhanan, K.K. Antioxidant activity of cultured mycelium of ten different species of oyster mushroom, Pleurotus: A comparative study. Int. J. Pharm. Sci. Res. 2015, 6, 1210-1216.

38. Mishra, K.; Pal, R.; Bhatt, J. Comparison of antioxidant properties in cap and stipe of Lentinula edodes-A medicinal mushroom. Emir. J. Food Agric. 2015, 27, 562-569. [CrossRef]

39. Politowicz, J.; Lech, K.; Sánchez-Rodríguez, L.; Figiel, A.; Szumny, A.; Grubor, M.; Carbonell-Barrachina, Á.A. Volatile composition and sensory profile of oyster mushroom as affected by drying method. Dry. Technol. 2018, 36, 685-696. [CrossRef]

40. Chambers, E., IV; Bowers, J.A.; Dayton, A.D. Statistical designs and panel training/experience for sensory analysis. J. Food Sci. 1981, 46, 1902-1906. [CrossRef]

41. Chambers, E., IV; Smith, E.A. Effects of testing experience on performance of highly trained sensory panelists. J. Sens. Stud. 1993, 8, 155-166.

42. Chambers, D.H.; Allison, A.A.; Chambers, E., IV. Effects of training on performance of descriptive sensory panelists. J. Sens. Stud. 2004, 19, 486-499. [CrossRef]

43. Chanadang, S.; Chambers, E., IV. Sensory shelf life estimation of novel fortified blended foods under accelerated and real-time storage conditions. J. Food Sci. 2019, 84, 2638-2645. [CrossRef] [PubMed]

44. Chanadang, S.; Chambers, E., IV. Determination of the sensory characteristics of traditional and novel fortified blended foods used in supplementary feeding programs. Foods 2019, 8, 261. [CrossRef] [PubMed]

45. Kumar, R.; Chambers, E., IV. Lexicon for multi-parameter texture assessment of snack and snack-like foods in English, Spanish, Chinese, and Hindi. J. Sens. Stud. 2019, 34, e12500.

46. Chambers, E., IV. Consensus Methods for Descriptive Analysis. In Descriptive Analysis in Sensory Evaluation; Kemp, S., Hort, J., Hollowood, T., Eds.; Wiley Blackwell: Chichester, UK, 2018; pp. 213-236.

47. Caul, J.F. The Profile Method of Flavor Analysis. In Advances in Food Research; Mrak, E.M., Stewart, G.F., Eds.; Academic Press, Inc.: New York, NY, USA, 1957; Volume 7, pp. 1-40.

48. Wang, H.; Zhang, X.; Suo, H.; Zhao, X.; Kan, J. Aroma and flavor characteristics of commercial Chinese traditional bacon from different geographical regions. J. Sens. Stud. 2019, 34, e12475. [CrossRef]

49. Cano-Lamadrid, M.; Turkiewicz, I.P.; Tkacz, K.; Sánchez-Rodríguez, L.; López-Lluch, D.; Wojdyło, A.; Sendra, E.; Carbonell-Barrachina, A.A. A critical overview of labeling information of pomegranate juice-based drinks: Phytochemicals content and health claims. J. Food Sci. 2019, 84, 886-894. [CrossRef]

50. Tran, T.; Chambers, E., IV. Development of a model system for tasting grain varieties. Foods 2020, 9, 510. [CrossRef]

51. Godoy, R.C.B.; Chambers, E., IV; Yang, G. Development of a preliminary sensory lexicon for Yerba Mate tea. J. Sens. Stud. 2020, 35, e12570. 
52. Sanchez, K.; Chambers, E., IV. How does product preparation affect sensory properties? An example with coffee. J. Sens. Stud. 2015, 30, 499-511. [CrossRef]

53. Oupadissakoon, G.; Chambers, D.H.; Chambers, E., IV. Comparison of the sensory properties of UHT milk from different countries. J. Sen. Stud. 2009, 24, 427-440. [CrossRef]

54. Chambers, E., IV; Robel, A. Sensory characteristics of selected species of freshwater fish in retail distribution. J. Food Sci. 1993, 58, 508-512, 561.

55. Murley, T.; Chambers, E., IV. The influence of colorants, flavorants, and product identity on perceptions of naturalness. Foods 2019, 8, 317. [CrossRef] [PubMed]

56. Chambers, E.V.; Tran, T.; Chambers, E., IV. Natural: A $\$ 75$ billion word with no definition-Why not? J. Sensory Stud. 2019, 34, e12501. [CrossRef]

57. Chambers, E.V.; Chambers, E., IV; Castro, M. What is "Natural"? Consumer responses to selected ingredients. Foods 2018, 7, 65. [CrossRef] [PubMed]

58. Morse, R.E. How phosphates can benefit meats. Food Eng. 1955, 27, 84-86.

59. Hargett, S.M.; Blumer, T.N.; Hamann, D.D.; Keeton, J.T.; Monroe, R.J. Effect of sodium acid pyrophosphate on sensory, chemical, and physical properties of frankfurters. J. Food Sci. 1980, 45, 905-911. [CrossRef]

60. Johnson, R.C.; Chen, C.M.; Muller, T.S.; Costello, W.J.; Romans, J.R.; Jones, K.W. Characterization of the muscles within the beef forequarter. J. Food Sci. 1988, 53, 1247-1250. [CrossRef]

61. Lyon, B.G. Descriptive profile analysis of cooked, stored, and reheated chicken patties. J. Food Sci. 1988, 53, 1086-1090. [CrossRef]

62. Yenket, R.; Chambers, E., IV. Influence of cluster analysis procedures on variation explained and consumer orientation in internal and external preference maps. J Sens Stud. 2017, 32, e12296. [CrossRef]

63. Yenket, R.; Chambers, E., IV; Adhikari, K. A comparison of seven preference mapping techniques using four software programs. J. Sensory Stud. 2011, 26, 135-150. [CrossRef]

64. Keeton, J.T.; Foegeding, E.A.; Patana-Anake, C. A comparison of nonmeat proteins, sodium tripolyphosphate and processing temperature effects on physical and sensory properties of frankfurters. J. Food Sci. 1984, 49, 1462-1465. [CrossRef]

(C) 2020 by the authors. Licensee MDPI, Basel, Switzerland. This article is an open access article distributed under the terms and conditions of the Creative Commons Attribution (CC BY) license (http://creativecommons.org/licenses/by/4.0/). 